\title{
Commercial Mining Activities in the Deep Seabed beyond National Jurisdiction: the International Legal Framework
}

\author{
Joanna Dingwall
}

The deep seabed beyond national jurisdiction covers approximately half of our planet, yet it is the most inaccessible and least explored area on earth. ${ }^{1}$ It is home to a wealth of mineral resources, including a variety of valuable metals and rare earth elements. ${ }^{2}$ Deep seabed minerals await discovery on volcanic ridges, rocky outposts and amongst the sediment of the ocean floor, typically at depths of up to around 5,000 metres. $^{3}$

The United Nations Convention on the Law of the Sea (UNCLOS or the Convention) established the regime which governs mining in the deep seabed beyond national jurisdiction (referred to in this Chapter as the 'deep seabed' or the 'Area'). ${ }^{4}$ The Convention defines the Area as comprising 'the seabed and ocean floor and subsoil thereof, beyond the limits of national jurisdiction.' ${ }^{5}$ At present, as many coastal States have still to determine the outer boundaries of

1 The author's analysis of the status of the deep seabed mining regime, and the extent of mining activities within it, is current as at 1 November 2018. All web links cited in this Chapter are correct as at that date. The views expressed herein are those of the author alone and do not necessarily represent the views of the Scottish Government or the University of Glasgow. Elements of this Chapter are also addressed by this author in Joanna Dingwall, 'The International Legal Regime Applicable to the Mineral Resources of the Deep Seabed' (2018) 9 Eur YB of Intl Economic L 261-287.

2 International Seabed Authority 'Marine Mineral Resources' (2003) <www.isa.org.jm/files/ documents/EN/Brochures/ENG6.pdf>; Jim Hein 'ISA Briefing Paper 02/12 - Prospects for Rare Earth Elements from Marine Minerals' (May 2012) <www.isa.org.jm/files/documents/ EN/Pubs/BP2.pdf >.

3 ISA, 'Marine Mineral Resources' (n2).

4 United Nations Convention on the Law of the Sea (adopted and opened for signature 10 December 1982, entered into force 16 November 1994) 1833 UNTS 3, Part XI and Annex III.

5 UNCLOS, art 1(1). 
their continental shelves, the precise boundaries of the Area remain 'fluid.' However, to put the size of the Area into perspective, it constitutes approximately 260 million square kilometres, which is around $72 \%$ of the total surface area of the oceans. ${ }^{7}$

UNCLOS created the International Seabed Authority (ISA or the Authority), which is the autonomous international organisation charged with overseeing and administering a system for deep seabed mining. ${ }^{8}$ The ISA is responsible for regulating the Area and granting contracts (also referred to as licences) to explore for and exploit deep seabed mineral resources. ${ }^{9}$ The regime incorporates various key elements, including benefit-sharing aspects and marine environmental protections. ${ }^{10}$ Moreover, the ISA is empowered to develop a comprehensive Mining Code, intended to augment the regime and govern the entire lifecycle of deep seabed mining operations. ${ }^{11}$

In relation to deep seabed mining in the Area, the Convention defines 'resources' as 'all solid, liquid or gaseous mineral resources in situ in the Area at or beneath the sea-bed, including polymetallic nodules.'12 Once extracted from the Area, such resources are referred to as 'minerals."13 The Area and its resources constitute 'the common heritage of mankind.'14 As the UNCLOS

Michael W Lodge, ISA Secretary-General, 'Statement to the Open Meeting of the Commission on the Limits of the Continental Shelf' (United Nations, New York, 10 March 2017) 4 <www.isa.org.jm/files/documents/EN/SG-Stats/2017/CLCS-10Mar17. pdf $>$. For analysis of the boundary between national jurisdiction and the Area, see Chapter 4 of this book, H. Brekke 'Setting maritime limits and boundaries: Experiences from Norway' See also, e.g., Erik Franckx, 'The 200 Mile Limit: Between Creeping Jurisdiction and Creeping Common Heritage?' (2007) 39 George Washington Intl Rev 467; Erik Franckx, 'The International Seabed Authority and the Common Heritage of Mankind: The Need for States to Establish the Outer Limits of their Continental Shelf' (2010) 25 Intl J Marine and Coastal L 543.

$7 \quad$ Michael W Lodge, 'Satya Nandan's Legacy for the Common Heritage of Mankind' in Michael W Lodge and Myron H Nordquist (eds), Peaceful Order in the World's Oceans (Brill 2014) 290, fn22. See also BW Eakins and GF Sharman, 'Volumes of the World's Oceans from ETOPOı' (National Oceanic and Atmospheric Administration (NOAA), National Geophysical Data Center 2010) <www.ngdc.noaa.gov/mgg/global/etopo1_ ocean_volumes.html > (the surface area of the oceans is 361.9 million square kilometres). UNCLOS, art 156 .

$9 \quad$ UNCLOS, arts 153, 157(1) and see also Annex III.

10 See, e.g., UNCLOS, arts 140, 145, 148.

11 For further consideration of the ISA's Mining Code, see Chapter 25 of this book, K. Svendsen, 'Liability and Compensation for Activities in the Area'.

12 UNCLOS, art 133(a).

13 UNCLOS, art 133 (b).

14 UNCLOS, art 136. 
deep seabed mining regime is not applicable to living resources, controversy remains as to whether marine genetic resources constitute part of the common heritage. ${ }^{15}$

The focus of this Chapter is to provide an introduction to the Convention's deep seabed mining regime and the extent of commercial activities currently occurring within it. In order to conduct this analysis, Section 2 of this Chapter provides a brief snapshot of the regime's historical development. Section 3 then evaluates the current scope of the UNCLOs deep seabed mining regime and the manner in which commercial actors may participate within it. Thereafter, Section 4 provides a flavour of the status of commercial mining activities in the Area so far. Finally, Section 5 provides concluding remarks on the deep seabed mining regime.

\section{The Development of the unclos Deep Seabed Mining Regime}

The mineral resources of the deep seabed have considerable economic potential. As early as the 1800 s, the HMs Challenger expedition had already discovered the existence of polymetallic nodules on the deep ocean floor. ${ }^{16}$ However, the economic prospects of deep seabed resources only began to catch the international community's imagination half a century ago. During the 196os, the prospective riches of the deep seabed began to seem within humanity's grasp. ${ }^{17}$ As technology advanced, for the first time the untold wealth of the seabed appeared tantalisingly close. ${ }^{18}$

15 For analysis of this issue, see: Chapter 10 of this book, T. Scovazzi, 'The Rights to Genetic Resources beyond National Jurisdiction: Challenges for the ongoing Negotiations at the United Nations'; Chapter 11 of this book, M.W. Tvedt, 'Marine genetic resources: A Practical Legal Approach to Stimulate Research, Conservation and Benefit Sharing'. See also, e.g., Konrad Jan Marciniak, 'Marine Genetic Resources: Do They Form Part of the Common Heritage of Mankind Principle?' in Lawrence Martin and others (eds), Natural Resources and the Law of the Sea: Exploration, Allocation, Exploitation of Natural Resources in Areas under National Jurisdiction and Beyond (Juris Publishing 2017).

16 See Chapter 3 of this book, Håkon With Andersen, 'A Short Human History of the Ocean Floor'. See also John Murray and Alphonse François Renard, 'Report on Deep-Sea Deposits Based on the Specimens Collected During the Voyage of HMS Challenger in the Years 1872 to 1876 ' (Neill \& Co for HM Stationary Office 1891).

17 See, e.g., John L Mero, The Mineral Resources of the Sea (Elsevier 1965).

18 See, e.g., UNGA First Committee (22nd Session) 'Speech by Arvid Pardo' (1 November 1967, 3 pm) UN Doc A/C.1/PV.1516, para 9. 
Throughout the 196os and 1970s, against the backdrop of decolonisation, entitlement to deep seabed resources became an ideological battleground, split into broadly two camps. ${ }^{19}$ In one camp were the industrialised States, favouring freedom for all States to exploit deep seabed resources on a firstcome, first-served basis. In the other camp were the developing States, fighting for a contrary system whereby deep seabed resources could be exploited only for the benefit of humanity. ${ }^{20}$ The latter camp were motivated by the realisation that without careful regulation, to allow freedom for all to exploit deep seabed resources would not be as egalitarian as it appeared ${ }^{21} \mathrm{~A}$ free-for-all system would in fact preserve deep seabed mining as the domain of the small number of wealthy States possessing the relevant technical expertise, who would be in prime position to carve up the spoils between them. ${ }^{22}$

In a remarkable feat, after decades of wrangling, the developing States achieved their vision in many key respects. The UnCLOs deep seabed regime, which was finally agreed in 1982 , is a unique scheme for common resource management. It is underpinned by the principle that the deep seabed constitutes 'the common heritage of mankind' and cannot be alienated unilaterally. ${ }^{23}$ This application of the common heritage concept to the deep seabed was a notion first formally introduced before the UN General Assembly by Malta's Ambassador, Arvid Pardo on 1 November $1967 .{ }^{24}$ In terms of the content of the common heritage concept, as commentary explains:

19 For further elaboration on the regime's historical development, see, e.g., Martti Koskenniemi and Marja Lehto, 'The Privilege of Universality: International Law, Economic Ideology and Seabed Resources' (1996) 65 Nordic J Intl Law 533, 536-552; RR Churchill and AV Lowe, The Law of the Sea (3rd edn, Manchester UP 1999) 224-229; ED Brown, Sea-Bed Energy and Minerals: The International Legal Regime, vol 2 (Martin Nijhoff Publishers 2001), Ch 2; Erkki Holmila, 'Common Heritage of Mankind in the Law of the Sea' (2005) 1 Acta Societatis Martensis 187; John E Noyes, 'The Common Heritage of Mankind: Past, Present, and Future' (2012) 40 Denver J Intl L \& Policy 447, 459-46o; Helmut Tuerk, 'The International Seabed Area' in Malgosia Fitzmaurice and Norman A Martinez Gutierrez (eds), The IMLI Manual on International Maritime Law, vol I (OuP 2014) 280-282. See, e.g., UNGA Res 2574 D (xxIV) (15 December 1969), which called for a moratorium on deep seabed mining in the Area, pending establishment of an international legal regime. Rosalyn Higgins, Problems \& Process - International Law and How We Use It (Clarendon Press 1994) 130-131.

22 Higgins (n21) 130-131; and Koskenniemi/Lehto 540; Churchill/Lowe 225; Noyes (2012) 459460 (all nig).

23 UNCLOS, arts 136 and 137, respectively.

24 UNGA First Committee (22nd Session) 'Speech by Arvid Pardo' (1 November 1967, 10.30 am) UN Doc A/C.1/PV.1515. See also Unga Res 2749 (xxv) (17 December 1970) (the Declaration of Principles Governing the Sea-Bed and the Ocean Floor, and the Subsoil 
The common heritage concept implied that [the deep seabed] was open to use by the international community, but was not owned by it. It required a system of management in which all users had a right to participate as well as an active sharing of benefits and reservation for future generations, and thus also had environmental implications. ${ }^{25}$

As this Chapter addresses further below, all of these elements are captured within the UNCLOS deep seabed mining regime.

Part XI of UNCLOS contains the legal regime applicable to deep seabed mining, and this is elaborated in Annex III, which details the licensing application process and conditions. However, industrialised States viewed Part XI as having swung too far in favour of developing States. ${ }^{26}$ The regime's particularly contentious features included requirements for mandatory transfer of technology, ${ }^{27}$ and the expansive role envisaged for the ISA's intended mining arm, the Enterprise, together with the subsidisation of the Enterprise by States

Thereof, Beyond the Limits of National Jurisdiction) (which captured Pardo's common heritage vision for deep seabed mining). For discussion of precursors to Pardo's speech by nineteenth century jurists, see Myron H Nordquist and others (eds), United Nations Convention on the Law of the Sea 1982: A Commentary, vol vi (Martinus Nijhoff Publishers 2002) 6-7; Michael W Lodge, 'International Seabed Authority's Regulations on Prospecting and Exploration for Polymetallic Nodules in the Area' (2002) $20 \mathrm{~J}$ Energy and Natural Resources L 270, 271, fn5; Kemal Baslar, The Concept of the Common Heritage of Mankind in International Law (Martin Nijhoff Publishers 1998) 80-81.

25 Tuerk (n19) 280. See also LFE Goldie, 'A Note on Some Diverse Meanings of "The Common Heritage of Mankind"' (1983) 10 Syracuse J Intl L and Commerce 69; Michael W Lodge, 'The Common Heritage of Mankind' (2012) 27 Intl J Marine and Coastal L 733. On the concept of the common heritage more broadly, including in relation to the seabed, the moon and Antarctica see, e.g., see Rüdiger Wolfrum, 'The Principle of the Common Heritage of Mankind' (1983) 43 Heidelberg J Intl L 312; Christopher C Joyner, 'Legal Implications of the Concept of the Common Heritage of Mankind' (1986) 35 ICLQ 190; Barbara Ellen Heim, 'Exploring the Last Frontiers for Mineral Resources: A Comparison of International Law Regarding the Deep Seabed, Outer Space, and Antarctica' (1990-91) 23 Vanderbilt J Transnational L 819; Baslar (n24); Graham Nicholson, 'The Common Heritage of Mankind and Mining: An Analysis of the Law as to the High Seas, Outer Space, the Antarctic and World Heritage' (2002) 6 New Zealand J Intl L 177; Jennifer Frakes, 'The Common Heritage of Mankind Principle and the Deep Seabed, Outer Space, and Antarctica: Will Developed and Developing Nations Reach a Compromise?' (2003) 21 Wisconsin Intl L J 409; Edward Guntrip, 'The Common Heritage of Mankind: An Adequate Regime for Managing the Deep Seabed?' (2003) 4 Melbourne J Intl L 376; Rüdiger Wolfrum, 'Common Heritage of Mankind' in R Wolfrum (ed), The Max Planck Encyclopedia of Public International Law (OUP 2009); Noyes (2012) (n19) 447.

26 Churchill/Lowe 231; Tuerk 282 (both n19).

27 As originally detailed in UNCLOS, Annex III, art 5. 
Parties. ${ }^{28}$ Therefore, for over a decade, there was a stalemate. Many industrialised States, including the United States (US), the United Kingdom (UK), Germany, France, Italy, Japan and Russia, refused to ratify UNCLOS, thereby impeding the Convention's entry into force. ${ }^{29}$

Eventually, in 1994, the international community reached a compromise. This took the form of the Agreement on the Implementation of Part XI of UNCLOS (1994 Agreement). ${ }^{30}$ Whilst retaining the tenor of the deep seabed regime as envisaged originally by UNCLOS, the 1994 Agreement made significant modifications to its operation, eliminating some of its more controversial aspects. ${ }^{31}$ For example, the 1994 Agreement removed from the regime both the subsidisation of the Enterprise and the mandatory transfer of technology requirements. ${ }^{32}$ In light of the 1994 Agreement's modification of the deep seabed mining regime, the Convention entered into force on 16 November 1994.

Presently, the UNCLOS deep seabed mining regime (as modified by the 1994 Agreement) enjoys broad support throughout the international community. The overwhelming majority of States are parties to UNCLOS (with perhaps the most notable exception being the US). Currently, UnCLOS has 168

28 As mandated previously by art 170(4) of UNCLOS, read in conjunction with arts 171 and $173(2)(\mathrm{b})$.

29 In numerical terms there were sufficient developing States to bring the Convention into force (only sixty State ratifications were necessary to achieve this, as per UNCLOS, art 308). However, in practice, the Convention system could not operate successfully without political and financial support from industrialised States. See Koskenniemi/Lehto (n19) 534-535, 542-544; Churchill/Lowe (n19) 230-231; Lodge (2002) (n24) 272.

30 Agreement Relating to the Implementation of Part XI of the United Nations Convention on the Law of the Sea of 10 December 1982 (adopted 28 July 1994, entered into force provisionally 16 November 1994 and definitively 28 July 1996) 1836 UNTS 3 .

31 On the fundamental changes which the 1994 Agreement introduced, see, e.g., DH Anderson, 'Further Efforts to Ensure Universal Participation in the United Nations Convention on the Law of the Sea' (1994) 43 ICLQ 886; Bernard H Oxman, 'The 1994 Agreement and the Convention' (1994) 88 AJIL 687; Louis B Sohn, 'International Law Implications of the 1994 Agreement' (1994) 88 AJIL 696; ED Brown, 'The 1994 Agreement on the Implementation of Part XI of the UN Convention on the Law of the Sea: Breakthrough to Universality?' (1995) 19 Marine Policy 5; LDM Nelson, 'The New Deep Sea-Bed Mining Regime' (1995) 10 Intl J Marine and Coastal L 189; Koskenniemi/Lehto (n19) 535, 549-551; RP Anand, 'Common Heritage of Mankind: Mutilation of an Idea' (1997) 37 Indian J Intl L 1; Churchill/Lowe (n19) 238, 248-251; Nordquist (n24) 4, 67; Lodge (2002) (n24) 272.

32 See 1994 Agreement, Annex ss2(3) and 5, respectively. In addition, the role of the Enterprise was curtailed significantly; 1994 Agreement, Annex s2. For discussion on all these points, see Nordquist (n24) 4. 
States Parties, including the European Union (EU). ${ }^{33}$ In addition, the ISA also has some 30 States participating in its activities as observers (including the US), together with various observer international organisations and NGOs. ${ }^{34}$ Moreover, many aspects of UNCLOS are recognised as having the status of customary law, binding on all States irrespective of whether or not they are parties to the Convention. ${ }^{35}$ Against this backdrop, Section 3 of this Chapter will now address key aspects of the Convention's deep seabed mining regime.

\section{The unclos Deep Seabed Mining Regime}

The UNCLOS deep seabed mining regime is contained within Part XI of the Convention and elaborated upon in Annex III, as modified by the 1994 Agreement. The provisions of Part XI of UNCLOS and the 1994 Agreement are to be interpreted and applied together as a single instrument; but, in the event of inconsistency between them, the provisions of the latter prevail. ${ }^{36}$ In addition, the ISA is augmenting the regime through adoption of rules to regulate deep seabed mining.

The following analysis addresses the key features of the regime (3.1), the means by which commercial operators can participate within the licensing process (3.2) and the position of actors outside of the regime (3.3).

\subsection{Key Elements of the UNCLOS Deep Seabed Mining Regime}

The premise of the UNCLOS deep seabed mining regime is that the deep seabed and its resources are the 'common heritage of mankind' ${ }^{37}$ and mining activities

33 The 1994 Agreement has 150 States Parties (all of which are also parties to UNCLOS itself). See United Nations Division for Ocean Affairs and the Law of the Sea, 'Chronological List of Ratifications of, Accessions and Successions to the Convention and the Related Agreements' (3 April 2018) <www.un.org/Depts/los/reference_files/chronological_lists_ of_ratifications.htm>.

34 UNCLOS, art 156(3); see also ISA, 'Observers' < www.isa.org.jm/observers > for the current list of ISA observers. See James Harrison, Making the Law of the Sea (CUP 2011) 128 on the role of these observers.

35 Churchill/Lowe (nı) 24; Alan Boyle and Christine Chinkin, 'UNCLOS III and the Process of International Law-Making' in Tafsir Malick Ndiaye and Rüdiger Wolfrum (eds), Law of the Sea, Environmental Law and Settlement of Disputes (Martinus Nijhoff Publishers 2007) 376, 380; Harrison (n34) 52-56; John E Noyes, "The Law of the Sea Convention and the United States of America' (2014) 47 Revue Belge de Droit Intl 15, 32.

$36 \quad 1994$ Agreement, art 2(1).

37 UNCLOS, art 136 . 
must be carried out 'for the benefit of mankind as a whole. ${ }^{38}$ Accordingly, the deep seabed mining system must take the interests of developing States into account and promote their effective participation..$^{39}$ Moreover, the ISA is charged with developing mechanisms to guarantee equitable sharing of financial and other economic benefits derived from the Area. ${ }^{40}$ Another key element of the regime is the protection of the marine environment. ${ }^{41}$ Fundamentally, pursuant to the regime, States and other actors are prohibited from conducting unilateral deep seabed mining activities. No State or entity can unilaterally claim sovereignty over the deep seabed or its resources. ${ }^{42}$ Rather, all exploration and exploitation activities in the Area are subject to the permission and oversight of the ISA. ${ }^{43}$

As an international organisation, the ISA has international legal personality, entitling it to the full range of international rights and duties of an international person. ${ }^{44}$ The two principal organs which establish the ISA's policies and govern its work are the Assembly, in which all States Parties are represented; and the 36-member Council elected by the Assembly, which functions as the ISA's executive organ. ${ }^{45}$ The Secretariat is the ISA's third principal organ and it conducts the ISA's administration. ${ }^{46}$ The ISA is also assisted by its Legal and Technical Commission (LTC), which is an organ of the Council, ${ }^{47}$

38 UNCLOS, art 140(1).

39 UNCLOS, arts 148, 152(2).

40 UNCLOS, arts 140(2), 160(2)(f)(i), 16o(2)(g) and 162(o)(i).

41 See, e.g., UNCLOS, art 145. For analysis of issues concerning environmental protection in deep seabed mining, see, e.g., Kristina M Gjerde, 'Challenges to Protecting the Marine Environment beyond National Jurisdiction' (2012) 27 Intl J Marine and Coastal L 839; Rüdiger Wolfrum, 'The Contribution of the Regulations of the International Seabed Authority to the Progressive Development of International Environmental Law' in Michael W Lodge and Myron H Nordquist (eds), Peaceful Order in the World's Oceans (Brill 2014); Tullio Scovazzi, 'The Exploitation of Resources of the Deep Seabed and the Protection of the Environment' (2014) 57 German YB Intl L 181; Aline L Jaeckel, The International Seabed Authority and the Precautionary Principle - Balancing Deep Seabed Mineral Mining and Marine Environmental Protection (Brill 2017) 121-131.

42 UNCLOS, art 137.

43 UNCLOS, art 137(2); see also arts 153 and 157(1) and 1994 Agreement, Annex, S1(1).

44 UNCLOS, art 176. See also Reparation for Injuries Suffered in the Service of the United Nations Case (Advisory Opinion) [1949] ICJ Rep 174, 179; Markos Karavias, Corporate Obligations Under International Law (OUP 2013) 121.

45 UNCLOS, arts 158(1), 159-162.

46 UNCLOS, arts 158(1), 166.

47 UNCLOS, arts 163(1)(b), 165. The Convention provided also for the Council to be supported by an Economic Planning Commission, but that body is not operational; see UNCLOS, arts 163(1)(a), 164; cf. 1994 Agreement, Annex, s1(4). 
and the Finance Committee, a subsidiary organ of the Assembly, composed of representatives of the Council. ${ }^{48}$ The Authority's mining arm, the Enterprise, is not yet operational. ${ }^{49}$

The ISA is a unique and unusual body with far-reaching institutional powers of a kind which are arguably unparalleled within the international legal system. ${ }^{50}$ It plays the crucial role of custodian of the deep seabed, a role which is enshrined in both UNCLOS and the 1994 Agreement. ${ }^{51}$ The ISA's mandate is expressed most clearly in Article 157(1) of UNCLOS, which provides that ' $[t]$ he Authority is the Organization through which States Parties shall, in accordance with [Part XI], organize and control activities in the Area, particularly with a view to administering the resources of the Area.' The ISA is entrusted with the role of organising, implementing and controlling activities in the Area 'on behalf of mankind as a whole.52 To that end, the ISA has the power to adopt rules and regulations to govern deep seabed mining activities, with the aim of developing a comprehensive Mining Code to regulate exploration and exploitation for all forms of resources in the Area. ${ }^{53}$

The Mining Code adds another layer to the Convention's byzantine deep seabed mining regime and constitutes secondary law by the ISA. ${ }^{54}$ The ISA is still in the process of creating a bespoke Mining Code to govern the entire lifespan of deep seabed mining operations. Thus far, the ISA has implemented three sets of regulations, which concern prospecting and exploration activities for three types of minerals (namely, polymetallic nodules, polymetallic

481994 Agreement, Annex, s9; see also s3(4), (7).

49 UNCLOS, art 170; 1994 Agreement, Annex, s2.

5o See, e.g., Rüdiger Wolfrum, 'Legitimacy of International Law and the Exercise of Administrative Functions: The Example of the International Seabed Authority, the International Maritime Organization (IMO) and International Fisheries Organizations' in Armin von Bogdandy and others (eds), The Exercise of Public Authority by International Institutions - Advancing International Institutional Law (Springer 2010) 917 (citing the ISA is a 'rare' example of an international entity 'exercising functions equivalent to those of States' on the basis that it exercises executive and legislative functions and has jurisdiction to enforce its rules directly via a binding dispute resolution system. As such, the ISA is 'without question, a prime example of what may be referred to as an international administration' (at 934)). See also Jaeckel (n41) 146-148.

$5^{1} \quad$ UNCLOS, art 137(2); see also arts 153 and 157(1) and 1994 Agreement, Annex, s1(1).

$5^{2}$ UNCLOS, art 153(1); see also art 137(2).

53 UNCLOS, arts 140(2), 145, 16o(2)(f), 162(o), 165(2)(f), and Annex III, art 17; 1994 Agreement, Annex, s1(1), (5)(f)-(g), (15). For analysis of the ISA's broad powers to progressively develop the deep seabed mining regime, see Harrison (n34) 122-123, $15^{2}$.

Karavias (n44) 121-122. 
sulphides and cobalt-rich ferromanganese crusts), ${ }^{55}$ together with environmental recommendations. ${ }^{56}$ Moreover, the ISA is working at present to develop regulations for the exploitation of all resource types within the Area, through an extensive stakeholder process. ${ }^{57}$

\subsection{Participating within the UNCLOS Licensing Regime for Deep Seabed Mining}

Under the terms of the ISA's licensing regime, only certain actors are entitled to apply to conduct deep seabed mining operations in the Area. ${ }^{58}$ The Convention provides that such activities in the Area may be carried out by States Parties to the Convention or by 'state entities or natural or juridical persons which possess the nationality of States Parties or are effectively controlled by them or their nationals, when sponsored by such States. ${ }^{.9}$ The ISA's exploration regulations echo this requirement of nationality or control. ${ }^{60}$ Therefore, non-State actors, such as private corporations, seeking to participate within the UNCLOS regime must obtain sponsorship from all States of which they are nationals, and ' $[\mathrm{i}] \mathrm{f}$ another State or its nationals exercises effective control, the sponsorship of that State is also necessary.61 Only upon receiving appropriate

55 ISA, Regulations on Prospecting and Exploration for Polymetallic Nodules in the Area (adopted 13 July 2000) ISBA/6/A/18, (updated 25 July 2013) ISBA/19/C/17 (Nodules Regulations); ISA, Regulations on Prospecting and Exploration for Polymetallic Sulphides in the Area (adopted 7 May 2010) ISBA/16/A/12/Rev.1 (Sulphides Regulations); ISA, Regulations on Prospecting and Exploration for Cobalt-Rich Ferromanganese Crusts in the Area (adopted 27 July 2012) ISBA/18/A/11 (Cobalt Regulations).

56 See, e.g., ISA LTC, 'Recommendations for the Guidance of Contractors for the Assessment of the Possible Environmental Impacts arising from Exploration for Marine Minerals in the Area' (1 March 2013) ISBA/19/LTC/8.

57 For an overview of this process, see ISA, 'Ongoing Development of Regulations on Exploitation of Mineral Resources in the Area' <www.isa.org.jm/legal-instruments/ ongoing-development-regulations-exploitation-mineral-resources-area $>$. The ISA's current draft exploitation regulations are ISA LTC, 'Draft Regulations on Exploitation of Mineral Resources in the Area' (9 July 2018) ISBA/24/LTC/WP.1/Rev.1.

$5^{8}$ For more detailed analysis by this author of the operation of the UNCLOS deep seabed mining regime, see Dingwall (n1).

59 UNCLOS, art $153(2)(\mathrm{b})$.

6o Nodules Regulations, reg 9(b); Sulphides Regulations, reg 9(b); Cobalt Regulations, reg $9(\mathrm{~b})$.

61 Responsibility and Obligations of States Sponsoring Persons and Entities with Respect to Activities in the Area (Advisory Opinion of 1 February 2011) ITLOS Reports 2011, 10 (ITLOS Advisory Opinion) para 77. This is confirmed also in Regulation 11(1)-(2) of the Nodules, Sulphides and Cobalt Regulations. Regulation 11(1) specifies that '[i]f the applicant has more than one nationality (...) each State involved shall issue a certificate of sponsorship.' 
sponsorship from a States Party will a non-State actor be entitled to submit an application to the ISA to conduct exploration or exploitation activities. ${ }^{62}$

Indeed, as the Seabed Disputes Chamber (Chamber) of the International Tribunal for the Law of the Sea (ITLOS) has emphasised, the "notion of "sponsorship" is a key element in the system for the exploration and exploitation of the resources in the Area. ${ }^{63}$ One purpose behind the sponsorship requirement is 'to achieve the result that the obligations set out in the Convention, a treaty under international law which binds only States Parties thereto, are complied with by entities that are subjects of domestic legal systems. ${ }^{\prime 64}$ Moreover, by entering into a contract with the ISA, a non-State contractor becomes directly bound to adhere to various international legal obligations concerning deep seabed mining. ${ }^{65}$

To similar effect, Regulation $11(2)$ requires that '[w] here the applicant has the nationality of one State but is effectively controlled by another State or its nationals, each State involved shall issue a certificate of sponsorship.'

62 The sponsorship scheme does not, however, apply to applications by States Parties, who, by virtue of their sovereign status, are not required to demonstrate sponsorship. See UNCLOS, Annex III, art 4(5): this interpretation is confirmed by ITLOS Advisory Opinion (n61) para 79 .

63 ITLOS Advisory Opinion (n61) para 74.

64 ITLOS Advisory Opinion (n61) para 75; as the Chamber acknowledged, this end is also achieved by virtue of the ISA's regulations, which apply to all contractors. Notably, States Parties are responsible for ensuring that any activities that they (or State-sponsored entities) conduct in the Area are carried out in conformity with the Convention regime; UNCLOS, art 139. Any States Party failing to discharge this responsibility will be held responsible at international law. However, as per UNCLOS, art 139(2), a States Party does not incur liability for wrongful activities of its sponsored entity if that States Party has taken 'all necessary and appropriate measures to secure effective compliance' by the sponsored entity; see also arts 153(4) and 138. See further ITLOS Advisory Opinion (n61) para 122 (considering the extent of sponsoring State liability for State-sponsored entities and endorsing a high standard of due diligence, encompassing a legal obligation upon States to apply the precautionary approach and best environmental practices); see also David Freestone, 'Responsibilities and Obligations of States Sponsoring Persons and Entities With Respect To Activities in the Area' (2011) 105 AJIL 755.

65 Karavias (n44) 124 ("[t]he Standard Clauses [to the ISA contract], in turn, transpose the content of the [UNCLOS] provisions regarding activities in the Area and of the [ISA] Regulations into the contractual arrangement, thus providing a nexus between [UNCLOS] and the secondary law enacted by the ISA and the contract for exploration.'). 
States or State-sponsored entities seeking to explore for and exploit deep seabed resources must submit a plan of work for the ISA's approval. Once approved by the ISA and signed, the plan of work takes the form of a contract between the ISA and the contractor. ${ }^{66}$

The UNCLOS regime was intended to function as a parallel system: States and State-sponsored entities would be permitted to conduct deep seabed mining activities in tandem with the ISA's mining arm, the Enterprise. ${ }^{67}$ To that end, it institutes a site-banking system, whereby a contractor's plan of work must specify a total area for exploration or exploitation which is 'sufficiently large and of sufficient estimated commercial value to allow two mining operations' and 'indicate the coordinates dividing the area into two parts of equal estimated commercial value. ${ }^{\prime} 8$ On that basis, the ISA designates one part of the submitted area as a 'reserved area.' ${ }^{69}$ Before the 1994 Agreement's modifications, the UNCLOS regime envisaged that mining activities in reserved areas would be conducted 'solely' by 'the Authority through the Enterprise or in association with developing States. ${ }^{\prime 70}$ However, the 1994 Agreement suspended the role of the Enterprise for the time being. ${ }^{71}$

Under the present regime, the State or entity which contributes a particular area to the ISA as a reserved area now has the right of first refusal to enter into a joint venture agreement with the Enterprise for exploration and exploitation of that reserved area. ${ }^{72}$ In the event that that right of first refusal is not exercised, it is open for developing States and entities sponsored by them, including private actors, to apply to explore and exploit the reserved area. ${ }^{73}$ In relation to sulphides and cobalt crusts exploration, the ISA modified the

66 UNCLOS, art 153(3) and Annex III, art 3(5); see also 1994 Agreement, Annex, s1(6)(a)(i).

67 UNCLOS, art 153(2).

68 UNCLOS, Annex III, art 8.

69 See UnCLOS, Annex III, art 8 and 1994 Agreement, Annex, s1(10).

70 UNCLOS, Annex III, art 8; see further art 9. See also UnCLOS, Annex IV.

711994 Agreement, Annex, s2. In the interim period, the ISA Secretariat performs the Enterprise's functions. The Secretariat is presently conducting a study into the Enterprise's operationalisation; the terms of reference for this study are contained in ISA Secretariat, 'Note on Issues Relating to the Operation of the Enterprise, in Particular, the Legal, Technical and Financial Implications for the Authority and for State Parties' (12 June 2014) ISBA/20/LTC/12, Annex. The Secretary-General anticipates that the Council will consider a full proposal for operationalisation of the Enterprise during 2019; IISD Reporting Services, 'Summary of the Twenty-Fourth Annual Session of the International Seabed Authority (Second Part): 16-26 July 2018' (29 July 2018) 25:168 Earth Negotiations Bulletin $10<$ http://enb.iisd.org/download/pdf/enb25168e.pdf > .

721994 Agreement, Annex, s2(5).

73 UNCLOS, Annex III, art 9(4). 
site-banking system further, permitting an applicant seeking permission to explore for sulphides or cobalt crusts to offer an equity interest in a joint venture arrangement to the Enterprise instead of submitting a reserved area. ${ }^{74}$ At present, the LTC is considering whether to amend the Nodules Regulations to align them with the approach to sulphides and cobalt crusts in this regard. ${ }^{75}$

Once exploitation commences, the ISA will oversee redistribution of financial and other economic benefits derived from the resources of the Area. These benefits are to be shared equitably, on a non-discriminatory basis, through a mechanism which the ISA has still to devise. ${ }^{76}$ Currently, deep seabed miners contemplating exploitation activities face continued levels of uncertainty, given that levels of fees and royalties and precise terms of exploitation contracts are still to be determined. However, despite this, the ISA's stakeholder consultation process provides a unique opportunity to harness input from a wide range of actors, including commercial operators and environmental experts. ${ }^{77}$ This process could facilitate achievement of an exploitation regime which allows commercially viable mining activities while ensuring appropriate safeguards for the environment and the common heritage principles at the heart of the regime.

Indeed, as Section 4 of this Chapter will demonstrate, notwithstanding the developing nature of the existing regime, participation in the Area is increasing. Various States, State actors and private entities are positioning themselves to take advantage of the perceived opportunities afforded by deep seabed resources. However, what is the position of actors which are positioned outside of the UNCLOS regime, such as States which are not parties to the Convention, or their nationals? This following Section will address this point.

\subsection{The Position of Actors outside of the UNCLOs Deep Seabed Mining Regime}

The result of the Convention's system for participation is that non-States Parties to UNCLOS (NSPS) are not eligible to participate within the regime. Equally, non-State actors which have the sole nationality of a NSP cannot

74 Sulphides Regulations, regs 16, 19; Cobalt Regulations, regs 16, 19.

75 ISA LTC, 'Report of the Chair of the Legal and Technical Commission on the Work of the Commission at the First Part of its Twenty-Fourth Session' (26 April 2018) ISBA/24/C/9 para 18; see also ISA Secretariat, 'Issues Related to the Possible Alignment of the Authority's Regulations on Prospecting and Exploration Concerning the Offer of an Equity Interest in a Joint Venture Arrangement' (6 February 2018) ISBA/24/LTC/4.

76 UNCLOS, art 140(2).

77 On this process, see text to $\mathrm{n} 57$ above and accompanying citations. 
obtain sponsorship and apply to the ISA to explore for or exploit deep seabed resources. Indeed, there is a strong argument that the UNCLos deep seabed mining regime now constitutes 'the only game in town' and any competing regime would 'surely be condemned as inconsistent with international law. 78

Arguably, elements of the Convention's deep seabed mining regime, such as its prohibition on unilateral mining activities in Article 137, may have attained the status of customary law. ${ }^{79}$ For example, Koskenniemi and Lehto categorise the UNCLOS deep seabed regime as 'having become part of the normative reality' and maintain that ' $\mathrm{u}]$ nilateral mining outside the Convention will be illegal. ${ }^{\prime 80}$ Various factors support this conclusion. The UNCLOS deep seabed mining regime is adhered to or recognised by the international community as a whole. ${ }^{81}$ This near-universal acceptance of the regime, coupled with the lack of contrary deep seabed mining practice outside of the regime (including by key NSPs), ${ }^{82}$ renders it difficult to refute the claim that a State or other actor undertaking unilateral deep seabed mining activities would violate customary law..$^{83}$ Egede reaches this conclusion upon an assessment of State practice, concluding that the UNCLOS regime is 'binding on all states (both states parties and non-states parties) and consequently no state, not even non-parties, may unilaterally embark on mining activities in the Area. ${ }^{84}$

78 Noyes (2012) (n19) 465 .

79 Custom is 'evidence of a general practice accepted as law'; Statute for the International Court of Justice (ICJ) (opened for signature 26 June 1945 as annex to UN Charter, entered into force 24 October 1945) UKTS 67 (1946), art 38(1)(b). See also ILC, 'Identification of Customary International Law - Text of the Draft Conclusions as Adopted by the Drafting Committee on Second Reading' (17 May 2018) UN Doc A/CN.4/L.908*, Draft Conclusion 2.

8 o Koskenniemi/Lehto (n19) $55^{-} 55^{2}$. Similarly see Jonathan I Charney, 'The United States and the Law of the Sea After UnCLOS III - The Impact of General International Law' (1983) 46(2) L and Contemporary Problems 37, 49; Holmila (n19) 202-205; Edwin Egede, Africa and the Deep Seabed Regime: Politics and International Law of the Common Heritage of Mankind (Springer 2011) 66-69; Noyes (2012) (n19) 465; Lodge (2014) (n7) 282-298.

81 As noted at text to $\mathrm{n}_{34}$ above, almost all NSPS to UNCLOS participate within the ISA as observer States. See also Lodge (2012) (n25) 737-738.

82 Cf. North Sea Continental Shelf Cases [1969] ICJ Rep 3, paras 72-74 (where the ICJ recognised that treaty provisions may generate new customary law provided that they have a 'fundamentally norm-creating character such as could be regarded as the basis for a general rule of law' (para 72). Moreover, in order for treaty provisions to create new customary rules, 'even without the passage of any considerable period of time, a very widespread and representative participation in the convention might suffice of itself, provided it included that of States whose interests were specially affected' (para 73)).

83 See, e.g., Nelson (n31) 202; Koskenniemi/Lehto (n19) 551-552; Holmila (n19) 205; Egede (n8o) 66-69; Noyes (2012) (n19) 465; Lodge (2014) (n7) 282-298.

84 Egede (n8o) 69. 
Certainly, the only definitive way in which NSPs can render their nationals eligible to undertake mining activities in the Area is through the ratification of UNCLOS. For example, as the US is not a party to UNCLOS, neither the US nor any US nationals are entitled to participate in the ISA's licensing system. Only by ratification of UNCLOS would the US be eligible to apply to the ISA for mining rights or to sponsor US entities who wish to obtain ISA approval to mine. Thus, only by acceding to UNCLOS could the US secure for itself and its nationals legally recognised, internationally enforceable deep seabed mining rights backed by investment protections and binding international dispute resolution options. ${ }^{85}$

Any entity conducting mining operations in the Area without ISA authorisation - and absent the rights of exclusivity and security of tenure that an ISA contract affords ${ }^{86}$ - would expose itself to tremendous risk. Given the significant investment required to mount deep seabed mining operations, it does not seem credible that an actor would engage in mining activities without a clear legal basis and enforceable legal title. ${ }^{87}$

This is borne out in practice: NSPS or their nationals are not in fact conducting mining activities in the Area outside of the U NCLOS regime. ${ }^{88}$ For example, the US maintains a domestic regime for exploration and exploitation of mineral resources in the Area: the Deep Seabed Hard Mineral Resources Act (US Act), which it enacted in $1980 .{ }^{89}$ At present, only two deep seabed exploration licences remain active under the US Act, and both of these are held by US

85 For detailed analysis by this author of the investment protections and dispute resolution options for deep seabed miners within the UNCLOS regime, see Joanna Dingwall, 'International Investment Protection in Deep Seabed Mining Beyond National Jurisdiction' (2018) 19 J World Investment \& Trade 890.

86 UNCLOS, art 153(6) and Annex III, arts 3(4)(c), 16; these rights are reflected in Standard Clauses 2.1 and 2.2 of ISA exploration contracts contained within the fourth annex to the Nodules Regulations, Sulphides Regulations and Cobalt Regulations. See also Charney (n8o) 50-51; Karavias (n44) 124-125.

87 John Noyes, 'Ocean Resources and US Acceptance of the LOS Convention' (Opinio Juris, 14 June 2012) <http://opiniojuris.org/2012/o6/14/ocean-resources-and-u-s-acceptance-of -the-los-convention/>. This sentiment holds equally true for the exploitation phase, once it begins: Brown (2001) (n19) 3 ('the very considerable investment needed to finance such exploitation would become available only if a legal regime could be created under which potential exploiters could acquire secure legal titles').

88 Lodge (2014) $\left(\mathrm{n}_{7}\right) 282-298$.

89 Deep Seabed Hard Mineral Resources Act 30 USC $\S$ 1401-1473 (2002) (USA); see also NOAA, Deep Seabed Mining Regulations for Exploration Licenses 15 Code of Federal Regulations $§ 970.1002016$. 
defence giant, Lockheed Martin..${ }^{90}$ However, as the US has recognised, in order for Lockheed Martin's US licence claims to be afforded 'international recognition' and security of tenure, the US would need to accede to UNCLOS. ${ }^{91}$ Indeed, the US Department of State opined that if Lockheed Martin proceeded with exploration activities absent such international recognition, this would violate its licence terms. ${ }^{92}$

In September 2017, the US National Oceanic and Atmospheric Administration (NOAA) addressed the interaction of these US licences with the UNCLOS deep seabed mining regime. Firstly, NOAA acknowledged that the US Act's 'express purpose' is to establish an interim deep seabed mining regime, pending US ratification of UNCLOS. ${ }^{93}$ As such, as NOAA explained, a licence under the US Act 'gives the holder the exclusive right to explore a specific area, but only as against other US entities. ${ }^{94}$ On this basis, '[a]ny rights a US company may have domestically are not secured internationally because US companies are not able to go through the internationally recognized process at the [ISA] established for Parties to [UNCLOS].95

In fact, instead of proceeding outside of the UNCLOS system, NSP nationals are structuring their investments in a way that permits participation within UNCLOS. For example, operating within the framework of UNCLOS, the UK has sponsored two applications to the ISA by a British corporation seeking to explore for polymetallic nodules. Both applications were made by UK Seabed Resources Ltd (UKSRL), which was incorporated in May 2012 and is a whollyowned subsidiary of Lockheed Martin. ${ }^{96}$

9o US Department of Commerce, NOAA, 'Deep Seabed Mining - Report to Congress'

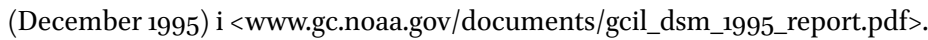

91 US Department of Commerce, NOAA, 'Extension of Deep Seabed Exploration Licenses: Response to Comments' (30 December 2015) Vol 80, Issue 250 FR 81529, 81530.

92 8o FR 81529 (ng1) 81530. To similar effect see also US Department of Commerce, NOAA, 'Deep Seabed Mining: Request for Extension of Exploration Licenses' (29 February 2012) Vol 77, Issue 40 FR 12245, 12246; US Department of Commerce, NOAA, 'Coastal Programs Division' (10 July 2012) Vol 77, Issue 132 FR 40586.

93 US Department of Commerce, NOAA, 'Deep Seabed Mining: Approval of Exploration License Extensions' (7 September 2017) Vol 82, Issue 172 FR 42327, 42328.

$94 \quad 82$ FR 42327 (n93) 42328.

$95 \quad 82$ FR 42327 (n93) 42328.

96 UKSRL is a wholly-owned subsidiary of Lockheed Martin UK Holdings Ltd, which is the UK-based component of Lockheed Martin Corporation. The Lockheed Martin conglomerate is headquartered in Maryland, US. 
Provided the test of effective control is met, ${ }^{97}$ the deep seabed regime contains no proscriptions to prevent a subsidiary constituted in the territory of a States Party and sponsored by that States Party from applying to engage in activities in the Area in this manner. Indeed, IT Los has confirmed implicitly the freedom of commercial actors to set up companies in foreign States and acquire the nationality and sponsorship of those States. ${ }^{98}$ Although the Chamber cautioned against "[t]he spread of sponsoring States "of convenience", this was in the context of determining whether developing and developed States were subject to the same responsibilities and liabilities when acting as sponsoring States. ${ }^{99}$ Therefore, by pursuing deep seabed mining activities through a UK subsidiary, US national Lockheed Martin managed to circumvent successfully the legal restrictions upon its participation.

In light of the above, deep seabed mining activity outside of the UNCLOS regime appears unlikely to occur at present due to the commercial, financial and legal risks and uncertainty that it would involve for any entity.

The Extent of Commercial Activities within the Area

\subsection{Commercial Prospects for Deep Seabed Mining in the Area and Environmental Concerns}

A host of actors are now participating in deep seabed mining activities in the Area. Currently, these activities are still at the exploration phase. Long-term commercial prospects for the deep seabed mining industry remain uncertain given the high costs and technological challenges involved in deep seabed mineral extraction, compounded by other factors such as fluctuating metal prices and environmental concerns. ${ }^{100}$

Notably, deep seabed mining faces major opposition on environmental grounds. ${ }^{101}$ On that basis, in January 2018, the European Parliament called

97 See discussion at text to $n n 59-61$ above.

98 ITLOS Advisory Opinion (n61) para 159.

99 IтLOS Advisory Opinion (n61) para 159 (the Chamber found that in order to prevent a race to the bottom, the regulatory burden must be equally applied to developing and developed States, otherwise corporations could choose to route their activities through the former to take advantage of lesser regulation).

100 Rahul Sharma, 'Deep-Sea Mining: Economic, Technical, Technological, and Environmental Considerations for Sustainable Development' (2011) Marine Technology Society J 45(5) 28, 28-31.

101 See overview in Luz Danielle O Bolong, 'Into the Abyss: Rationalizing Commercial Deep Seabed Mining through International Law' (2016) 25 Tulane J Intl \& Comparative L 127, 
for a moratorium on deep seabed mining until its impacts on the marine environment are more fully understood. ${ }^{102}$ Within civil society, a variety of NGOS oppose deep seabed mining, with the Deep Sea Mining Campaign supporting the ban of deep seabed mining activities in both international and national waters, and Greenpeace vehemently protesting future exploitation of deep seabed minerals. ${ }^{103}$ Deep seabed exploitation, in particular, presents certain common concerns irrespective of the type of mineral being exploited. These include direct destruction of habitats, together with marine degradation through plumes of seafloor sediments generated by mining activities and other resultant effects, such as underwater noise, vibration and light pollution. ${ }^{104}$

Environmental controversy notwithstanding, the exploitation phase of deep seabed mining may begin in the coming years. ${ }^{105}$ As the ISA's Secretary General remarked in February 2018, '[a]t a time when some appear to want to enter into an existential debate about whether deep sea mining should be permitted to go ahead or not, we do well to remember that the international community passed that point already many years ago.'106 Indeed, Michael Lodge, the current Secretary-General of the ISA, previously described the scale

141-146. For a scientific assessment of environmental concerns posed by deep seabed mining, see, e.g., Rahul Sharma, 'Environmental Issues of Deep-Sea Mining' (2015) 11 Procedia Earth \& Planetary Science 204. For detailed legal consideration of the balance between mineral exploitation and marine environmental protection, see, e.g., Jaeckel (n41); see also Gjerde (n41).

102 European Parliament, 'International Ocean Governance: An Agenda for the Future of our Oceans in the Context of the 2030 Sustainable Development Goals' (16 January 2018) < www.europarl.europa.eu/sides/getDoc.do?pubRef=-//EP//TEXT+TA+P 8-TA-2018-0004+0+DOC+XML+Vo//EN\&language $=\mathrm{EN}>$.

103 The Deep Sea Mining Campaign is an association of NGOs, including Oxfam Australia and Mining Watch Canada, together with other concerned individuals; Deep Sea Mining Campaign <www.deepseaminingoutofourdepth.org/>. See also Greenpeace International, 'Deep Sea Mining' (Background, 20 March 2014) <www.greenpeace.org/international/ en/campaigns/oceans/marine-reserves/deep-sea-mining/>. Greenpeace, alongside over 70 other NGOs, is part of the Deep Sea Conservation Coalition (an umbrella movement seeking to protect deep sea ecosystems): Deep Sea Conservation Coalition $<$ www.savethe highseas.org/>.

104 Sharma (2015) (n101) 205; Jaeckel (n41) 11-14.

105 See, e.g., ISA Press Release, 'Commercialization of Marine Minerals in Deep Seabed Well Within Reach, International Seabed Authority Secretary-General States as He Introduces Annual Report' (19 July 2016) SB/22/11.

106 Michael Lodge, ISA Secretary-General, 'Statement at the Workshop on the Draft Regulations for the Exploitation of Mineral Resources in the Area: Policy, Legal and Institutional Considerations' (London, 12-13 February 2018) 1 <www.isa.org.jm/sites/ default/files/documents/EN/SG-Stats/sg-statement_o.pdf>. 
of deep seabed mineral deposits as 'staggering.'107 Based on industry projections, by 2030, deep seabed mining could constitute $10 \%$ of all global mining activity and have a value of around $\$ 65$ billion in 2010 prices. ${ }^{108}$ Notably, this level of activity would be only the tip of the iceberg in terms of the potential resources present on the ocean floor. For example, the value of gold deposits lurking on the deep seabed has been calculated at $\$ 150$ trillion in 2013 prices. ${ }^{109}$

As noted above, thus far, licences for exploration relate to three particular types of minerals: polymetallic nodules, polymetallic sulphides and cobaltrich crusts. ${ }^{110}$ The first of these resource types, polymetallic nodules, are potato-sized rock deposits on the deep ocean floor, containing manganese, iron and other metals, such as copper and nickel. The second resource type, sulphides, generally contain iron, copper and zinc and may contain quantities of gold and silver. Most commonly, such sulphides emanate from hydrothermal vents on the mid-ocean ridge, where tectonic plates meet. Thirdly, cobalt crusts often form on rocky outcrops and ridges in the sea floor and contain elements such as manganese, iron, cobalt, nickel and lead. Each of these seabed deposits comprise relatively high concentrations of valuable metals as compared to equivalent minerals extracted on land. ${ }^{111}$ As terrestrial metal stocks become depleted due to rising material consumption, experts anticipate that

107 Michael Lodge, 'Deep Sea Mining: The New Frontier in the Struggle for Resources?' [2014] World Economic Forum <https://agenda.weforum.org/2014/11/ deep-sea-mining-the-new-frontier-in-the-struggle-for-resources/>.

108 European Commission, 'Blue Growth - Opportunities From the Marine and Maritime Sustainable Growth' сом (2012) 494 final, 10; Sheila Moorcroft, 'Ocean Mining - a Race to the Bottom' (Shaping Tomorrow, 17 April 2013) <www.shapingtomorrow.com/home/ alert/94162-Ocean-mining-a-race-to-the-bottom>.

109 Meghan Miner, 'Will Deep-Sea Mining Yield an Underwater Gold Rush?' National Geographic News (3 February 2013) <http://news.nationalgeographic.com/news/2013/ 13/130201-underwater-mining-gold-precious-metals-oceans-environment/ \#.UysXr_ldXGA>.

110 For an overview of the geological characteristics of these resource types, see Chapter 1 of this book, Alvar Braathen and Harald Brekke, 'Characterizing the Seabed - A Geoscience Perspective'. See generally Tim Schröder (ed), World Ocean Review: Marine Resources Opportunities and Risks, vol 3 (Maribus 2014).

111 James R Hein and others, 'Deep-Ocean Mineral Deposits as a Source of Critical Metals for High- and Green-Technology Applications: Comparison With Land-Based resources' (2013) 51 Ore Geology Reviews 1; see also Suzanne Goldenberg, 'Marine Mining: Underwater Gold Rush Sparks Fears of Ocean Catastrophe' The Observer (2 March 2014) <www.theguardian.com/environment/2014/mar/o2/ underwater-gold-rush-marine-mining-fears-ocean-threat>. 
corresponding costs will continue to rise. ${ }^{112}$ In this context, experts predict that metals extracted from the deep seabed will be increasingly sought after. ${ }^{113}$

Moreover, seabed minerals may contain traces of rare earth elements (REES). ${ }^{114}$ REES are highly desirable commodities: critical for the manufacturing of green energy technology, such as solar panels, wind turbines and hybrid cars, and in the weapons industry. They are also essential in the electronics industry for production of high-tech gadgets such as smart phones, laptops and flat-screen televisions. The volume of REEs available from the deep seabed could potentially exceed global land reserves of REEs. ${ }^{115}$ In this context, global excitement is growing over potential deep seabed mining for REEs in both national and international deep seabed areas. ${ }^{116}$ Deep seabed mining for REEs could be a viable means by which to secure a reliable supply chain, insulated from potential geopolitical ruptures.

As the following Section will address, in pursuit of deep seabed resources, commercial actors have already made significant investments, and there are indications that commercial mineral extraction could begin in the Area in the years to come. ${ }^{117}$

112 UN Environment Programme (UNEP), 'Wealth in the Oceans: Deep Sea Mining on the Horizon?' (Global Environmental Alert Service, May 2014) $1<$ https://na.unep.net/geas/ archive/pdfs/GEAS_May2014_DeepSeaMining.pdf $>$; Yves Fouquet and Denis Lacroix, 'Study Summary' in Yves Fouquet and Denis Lacroix (eds), Deep Marine Mineral Resources (Springer 2014) 5; European Commission, 'Report on Critical Raw Materials for the EU: Report of the Ad Hoc Working Group on Defining Critical Raw Materials' (May 2014) 9 <http://ec.europa.eu/DocsRoom/documents/10010/attachments/1/translations/en/ren ditions/native>; Houses of Parliament, Parliamentary Office of Science and Technology, 'Deep-Sea Mining' (POSTnote 508, September 2015) 1-2 <http://researchbriefings.files .parliament.uk/documents/POST-PN-0508/POST-PN-0508.pdf>.

113 European Commission (2012) (n108) 10; UNEP (n112) 1; Houses of Parliament (n112) 1-2.

114 Hein (n2) 1-2; Yves Fouquet and Bruno Martel-Jantin, 'Rare and Strategic Metals' in Yves Fouquet and Denis Lacroix (eds), Deep Marine Mineral Resources (Springer 2014) 63 ff.

115 Yasuhiro Kato and others, 'Deep-Sea Mud in the Pacific Ocean as a Potential Resource for Rare-Earth Elements' (2011) 4 Nature Geoscience 535, 538.

116 Ian Coles, 'Rare Earth Elements: Deep Sea Mining and the Law of the Sea' (2014) 14 Pratt's Energy L Rep 4, 8-10; Bolong (n101) 134-135.

117 See, e.g., ISA Press Release (n105); see also UNEP (n112); Houses of Parliament (n112). See further David Shukman, 'Deep Sea Mining "Gold Rush” Moves Closer' BBC News Online (18 May 2013) <www.bbc.co.uk/news/science-environment-22546875>; Goldenberg (nu11); Adam Minter, 'Seafloor Gold Rush Could Have Alarming Impact' Japan Times (21 August 2016) <www.japantimes.co.jp/opinion/2016/o8/21/commentary/worldcommentary/seafloor-gold-rush-alarming-impact/\#.W2sBQLllJaQ>; Julie Packard and Chris Scholin, 'The Deep Sea May Soon Be Up for Grabs' New York Times (8 June 2018) $<$ www.nytimes.com/2018/o6/08/opinion/the-deep-sea-may-soon-be-up-for-grabs.html>. 


\subsection{Current Participants in Deep Seabed Mining Activities in the Area}

As of the end of 2018, the ISA has entered into mining contracts with twentynine contractors for exploration in relation to the three minerals types currently regulated (nodules, sulphides and cobalt-rich crusts). ${ }^{118}$ These figures include a significant increase in the number of contracts granted in recent years. As recently as early 2011, the ISA had approved only eight applications for exploration; by late 2015, that figure had more than tripled.

The total area of deep seabed which the IsA has approved for exploration now surpasses 1.3 million square kilometres: an area approximately equivalent to the land mass of Sweden, Norway, Finland, Iceland and Denmark combined. ${ }^{119}$ Although this approved area may seem vast, in fact it represents only half a percent of the entire deep seabed beyond national jurisdiction which is open to licencing by the ISA.

The ISA holds exploration contracts with a wide variety of actors, including States, State enterprises, State institutions, State-controlled corporations and several private corporations. At present, of the existing twenty-nine contracts, one is held by an international consortium of States (exploring for nodules), eight are held by States (exploring for nodules, sulphides or cobalt crusts), and fifteen are held by State enterprises, State institutions or State-controlled corporations (of which nine contracts are for nodules exploration and the remainder concern exploration for sulphides or cobalt crusts). In terms of State or State-controlled activity, the nations which have been most active so far in securing ISA licences are China, Russia, and South Korea. These three States are the only ones to hold exploration contracts relating to all of the three types of mineral which are currently regulated. At present, China has the greatest number of licences of any State or national. China's fourth contract for deep seabed mineral exploration rights (and its second in respect of nodules) was signed in 2017 by the ISA and China's State-owned metals and minerals trading company, China Minmetals Corporation.

The remaining five ISA contractors are private corporations exploring for polymetallic nodules (with two active in reserved areas). The first private

118 Seventeen of the ISA's mining contracts relate to nodules exploration, seven are for sulphides exploration, and five are for exploration of cobalt-rich crusts. For an overview, see ISA, 'Deep Seabed Minerals Contractors' <www.isa.org.jm/deep-seabed -minerals-contractors $>$.

119 This figure includes all areas approved for exploration, excluding any reserved areas which are not currently subject to exploration. For information on the exploration contracts approved by the ISA to date, including details of size and location of exploration sites, see the ISA website: <www.isa.org.jm/>. 
actor to enter a contract with the ISA for nodules exploration was Tonga Mining Offshore Limited (TMOL) in 2012. ${ }^{120}$ The contract concerns portions of reserved areas originally contributed by French, German and Japanese State entities and South Korea. A Tongan national, TMOL is a wholly-owned subsidiary of Canadian mining company Nautilus Minerals Inc (Nautilus).

In 2013, Belgian corporation, G-Tec Sea Minerals Resources NV (GSR), and UK corporation, UKSRL, both entered contracts with the ISA. ${ }^{121}$ In March 2016, UKSRL entered a second contract with the ISA for nodules exploration. ${ }^{122}$ As noted above, UKSRL is a subsidiary of the US defence giant, Lockheed Martin. The remaining private contractor in the Area is Ocean Mineral Singapore Pte Ltd (OMS), a Singaporean corporation with an IsA contract to explore for nodules in a reserved area originally contributed by UKSRL. ${ }^{123}$

In addition to acting directly as contractors, some private corporations also have links to activities in the Area by State-controlled actors. For example, the Cook Islands Investment Corporation (CIIC), a State enterprise, entered a contract with the ISA in July 2016 for nodules exploration. ${ }^{124}$ CIIC entered into a joint venture agreement with GSR to jointly explore the area within CIIC's ISA contract, under the proviso that future profits would be shared equally between CIIC and GSR. ${ }^{125}$

120 ISA Council, 'Decision of the Council Relating to a Request for Approval of a Plan of Work for Exploration for Polymetallic Nodules Submitted by Tonga Offshore Mining Limited' (19 July 2011) ISBA $/ 17 / \mathrm{C} / 15$.

121 ISA Council, 'Decision of the Council of the International Seabed Authority Relating to a Request for Approval of a Plan of Work for Exploration for Polymetallic Nodules Submitted by G-TEC Sea Mineral Resources NV' (26 July 2012) ISBA/18/C/28; ISA Council, 'Decision of the Council of the International Seabed Authority Relating to a Request for Approval of a Plan of Work for Exploration for Polymetallic Nodules Submitted by UK Seabed Resources Ltd' (26 July 2012) ISBA/18/C/27.

122 ISA Council, 'Decision of the Council Relating to an Application for the Approval of a Plan of Work for Exploration for Polymetallic Nodules Submitted by UK Seabed Resources Ltd' (21 July 2014) ISBA/20/C/25.

123 ISA Council, 'Decision of the Council Relating to an Application for the Approval of a Plan of Work for Exploration for Polymetallic Nodules Submitted by Ocean Mineral Singapore Pte Ltd' (21 July 2014) ISBA/20/C/27. OMS is majority owned by Keppel Corporation, a Singaporean corporation and one of the world's largest offshore and marine groups. Minority shares in oms are held by UKSRL and Lion City Capital Partners Pte Ltd, a Singaporean private investment company.

124 ISA Council, 'Decision of the Council Relating to an Application for the Approval of a Plan of Work for Exploration for Polymetallic Nodules Submitted by the Cook Islands Investment Corporation' (21 July 2014) ISBA/20/C/29.

125 SOPAC, 'Cook Islands Enters New International Seabed Minerals Arrangement in Cooperation with GSR of Belgium' (The Prospect, 3 January 2014); Michael Henry, 
In practical terms, joining forces with private actors may provide developing States lacking in technical capabilities and resources, one of the only viable means by which to become active in deep seabed mining. ${ }^{126}$ For example, in its application, CIIC stated that its combined approach with GSR would '[enable them] to enhance all relevant synergies in scientific, ecological and economical research and studies to the absolute maximum.'127

To sum up, exploration activities in the Area are increasing, and this is especially so for private corporate contractors. Despite remaining uncertainties concerning long-term commercial prospects of deep seabed mining, increasing investment in the industry gives a strong indication that it may soon proceed towards commercialisation.

In the coming years, commercial extraction of deep seabed minerals may become feasible. As this Chapter has explored, despite continued uncertainties and challenges within the deep seabed mining industry, commercial investment in deep seabed mining is growing, and the volume of exploration activities in the Area continues to rise. An increasing number of States, State entities and private investors are now participating in deep seabed exploration activities under the ISA's licensing process within the UNCLOS regime. In this context, the ISA Secretary-General anticipates that deep seabed mining beyond national jurisdiction is 'well within reach' and 'attainable in the foreseeable future. 128

Under international law, there is a detailed legal framework for deep seabed mining activities within the Convention and associated instruments, including the 1994 Agreement and the ISA's Mining Code. All deep seabed mining activities in the Area are occurring under the auspices of this UNCLOS regime.

'International Seabed Authority Contract Signing' (Cook Islands Investment Corporations Online News, July 2016) <http://ciiconline.com/latestnews/international-seabed -authority-contract-signing/>. In an interesting dynamic, the area which CIIC intends to explore is a reserved area which was originally contributed by GSR pursuant to its 2013 nodules exploration contract with the ISA.

126 Tuerk (n19) 301.

127 ISA LTC, 'Application for Approval of a Plan of Work for Exploration for Polymetallic Nodules by the Cook Islands Investment Corporation' (8 November 2013) ISBA/20/LTC/3 para 13 .

128 ISA Press Release (n105). 
In practice, one key test for the future success of the regime will be the precise shape of the ISA's expanding regulatory code governing the exploitation phase, including its financial terms and environmental protections. Therefore, the ISA's current efforts to draft workable exploitation regulations, which takes on board the views of stakeholders in the industry, is a crucial movement towards the long-term realisation of a viable deep seabed mining industry in the Area. 